\title{
LAYERED MANTLE AT THE EDGE OF THE KARELIAN CRATON: P-T OF MANTLE XENOCRYSTS AND XENOLITHS FROM EASTERN FINLAND KIMBERLITES
}

\author{
Marja Lehtonen, Hugh O'Brien, Petri Peltonen, Bo Johanson and Lassi Pakkanen \\ Geological Survey of Finland, P.O. Box 96, SF-02151 Espoo, Finland
}

\section{ABSTRACT}

Chrome diopside (CD) and pyrope garnet xenocrysts from four kimberlite pipes in the Kaavi-Kuopio area of Eastern Finland have been studied using major and trace element analyses by EPMA and LA ICP-MS to obtain information on the vertical compositional variability of the underlying mantle. Combining the more complete mantle record of the xenocrysts with the petrological constraints provided by xenoliths makes interpretation of a relatively complete section through the lithospheric mantle possible. Single-grain CD thermobarometry fits relatively well with a $36 \mathrm{~mW} / \mathrm{m} 2$ geotherm calculated using heat flow constraints and P$\mathrm{T}$ data derived from xenoliths. Ni thermometry on pyrope xenocrysts gives $700-1350{ }^{\circ} \mathrm{C}$ and, based on the chrome diopside/xenolith geotherm, indicates a wide sampling interval, ca. 90-240 km. Plotting pyrope major and trace element compositions as a function of temperature shows there are three distinct layers in the underlying lithospheric mantle: 1. A significant low temperature (700-850 degrees) Ca-rich but Ti, $\mathrm{Y}$ and $\mathrm{Zr}$ depleted "wehrlitic" pyrope-bearing mantle of finegrained modally metasomatized (phlogopite-bearing) garnet-spinel harzburgites. 2. A variably depleted lherzolite (G9) and harzburgite (G10) bearing horizon from $900-1200$ degrees, or 150 to $185 \mathrm{~km}$. 3. A fertile deep layer from 180 to $250 \mathrm{~km}$ representing Proterozoic underplating and/or subducted lithosphere or a meltenriched version of layer 2 .

\section{INTRODUCTION}

The Neoproterozoic Eastern Finland Kimberlite Province situated at the edge of the Karelian Craton comprises two distinct clusters, Kaavi and Kuopio, of at least nineteen kimberlites with mineralogy typical of Group I kimberlite (Tyni 1997, O’Brien \& Tyni 1999). The pipes were emplaced into Archaean (3.1-2.6 Ga) basement gneisses and allocthonous Proterozoic (1.9$1.8 \mathrm{Ga}$ ) metasediments thrust onto the craton during the Svecofennian orogeny (Kontinen et al. 1992; Fig. 1). Several methods have been used to date the kimberlite magmatism (Tyni 1997, Peltonen et al. 1999, Peltonen

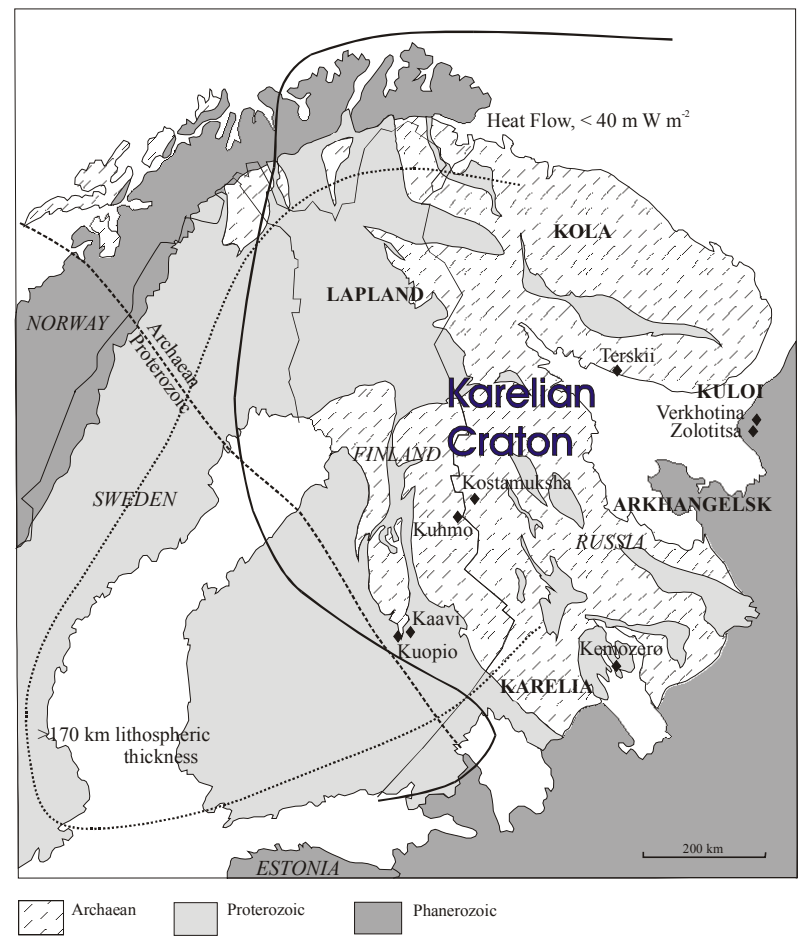

Figure 1: The map presents the diamond prospective area in Northern Europe where there is a low heat flow (simplified from Kukkonen \& Jõeleht 1996) and where the lithosphere is thicker than $170 \mathrm{~km}$ based on seismic data (Calcagnile 1982). Generalised geology is modified after Gaál and Gorbatschev (1987). The Archaean/Proterozoic boundary marks the subsurface extent of the Archaean craton. The black diamonds represent diamond-bearing kimberlites and lamproites.

\& Mänttäri 2001) but the U-Pb ion probe ages of 589$626 \mathrm{Ma}$ from perovskites are considered to be the most reliable (O'Brien H., unpublished). Mantle xenoliths from the Kaavi-Kuopio pipes have been studied in detail by Peltonen et al. (1999) and a geotherm on the order of $36 \mathrm{~mW} / \mathrm{m}^{2}$ has been calculated using xenolith P-T data and heat flow constraints (Kukkonen \& Peltonen 1999). However, due to the rarity of the xenoliths, they represent a more limited sampling of the lithospheric mantle compared to the xenocryst record, which is presumably more complete from the bottom to the top of the lithosphere. In order to obtain information on the vertical compositional variability of the litho- 
sphere, a systematic garnet and chrome diopside xenocryst study was carried out on four Kaavi-Kuopio kimberlites at the Geological Survey of Finland (GTK).

\section{SAMPLES}

Samples were selected from 4 kimberlites: 2 ha Lahtojoki (Pipe no. 7 with $26 \mathrm{cpht}$ of $+0.8 \mathrm{~mm}$ diamonds), 2 ha Kylmälahti (no. 17, marginally diamondiferous), 700 m x 30 m Kärenpää (no. 5) and $300 \times 50 \mathrm{~m}$ Niilonsuo (no. 2, microdiamond-rich). Xenocrysts were liberated by lightly crushing the kimberlite material - except for the hard Niilonsuo kimberlite which was fragmented electrodynamically at Forschungszentrum Karlsruhe $\mathrm{GmbH}$ (i.e. Vaasjoki \& Lindqvist 2001) - followed by HMS and handpicking. Garnet populations were chosen to be representative of the entire range within the kimberlites unaffected by sorting effects of handpicking specific grain colors.

\section{ANALYTICAL TECHNIQUES}

Mineral compositions were determined by a Cameca Camebax SX50 electron microprobe at GTK. An acceleration voltage of $25 \mathrm{kV}$, probe current of $48 \mathrm{nA}$, and beam diameter of 1 micrometer were applied. Selected garnet xenocrysts were analysed for trace elements at the University of Cape Town using a Perkin Elmer / Sciex Elan 6000 inductively coupled plasma spectrometer connected to a Cetac LSX-200 laser ablation module. Data was calibrated against an inhouse standard. Trace Ni, Mn and Ti data by electron microprobe were obtained on pyropes employing 500 nA probe current, 600s counting times on peak plus background positions and were reduced by the CSIRO TRACE program for the SX50 (Robinson \& Graham, 1992). Cross-checking of the two trace methods shows that $\mathrm{Ni}, \mathrm{Ti}$ and $\mathrm{Mn}$ analyses in pyrope by electron probe can achieve similar precision to those of LA ICP-MS down to the level of ca. $10 \mathrm{ppm}$.

The garnets were classified into harzburgitic, lherzolitic and non-peridotitic varieties according to Gurney (1984); the compositional field for wehrlitic garnet was separated from the lherzolite field using the division of Sobolev et al. (1973). Equilibration pressures and temperatures of the chrome diopside xenocrysts were calculated using the clinopyroxene thermobarometer of Nimis \& Taylor (2000, NT hereafter). Xenolith P-T data were calculated using NT and the method of Brey et al., 1990 (BKN hereafter). For garnet xenocrysts the $\mathrm{Ni}$ thermometer based on the partitioning of $\mathrm{Ni}$ between garnet and olivine was applied using the method of
Griffin et al. (1989) as recalibrated by Ryan et al. (1996).

\section{RESULTS}

\subsection{CHROME DIOPSIDE}

Single-grain chrome diopside thermobarometry fits reasonably well with a geotherm of $36 \mathrm{~mW} / \mathrm{m}^{2}$ calculated using heat flow constraints and xenolith P-T data from Finland (Kukkonen \& Peltonen 1999). Fig. 2 shows the correspondence between the xenolith and xenocryst data. Although there is a shift to lower pressures and slightly lower temperatures in NT results relative to BKN when compared from the same xenoliths, these shifts are along modeled heat flow curves and therefore do not affect the fit of the data to the preferred geotherm (Fig. 2, in blue).

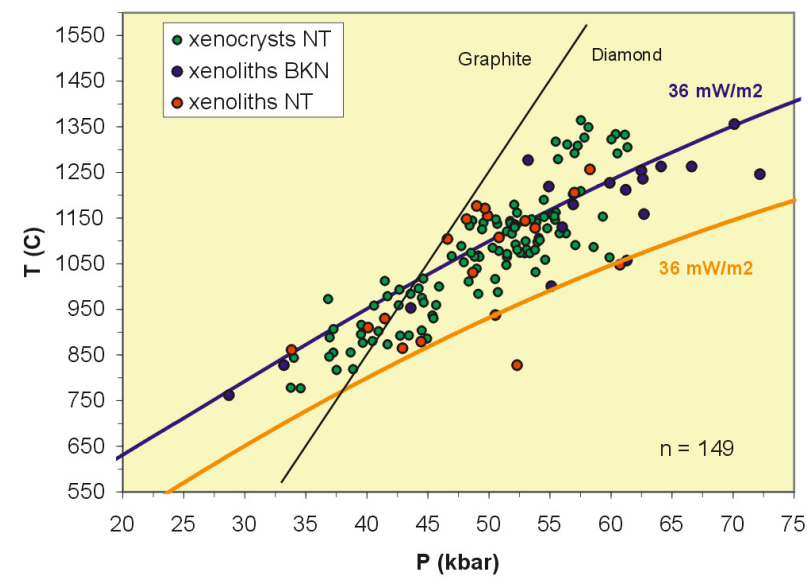

Figure 2: P-T calculated for Kaavi-Kuopio mantle based on chrome diopside data xenocrysts using NT and xenoliths using BKN and NT thermobarometers. Reference model geotherm for $36 \mathrm{~mW} / \mathrm{m}^{2}$ from Pollack \& Chapman (1977) in orange and $36 \mathrm{~mW} / \mathrm{m}^{2}$ calculated for the 600 Ma Karelian craton from Kukkonen \& Peltonen (1999) in blue.

\subsection{PYROPE}

$\mathrm{CaO}$ vs. $\mathrm{Cr}_{2} \mathrm{O}_{3}$ of pyropes subdivided by kimberlite and categorized using the systems of Sobolev et al. (1973) and Gurney (1984) are shown in Fig 3. From this diagram it is clear that lherzolitic pyrope predominates, a well-developed wehrlitic pyrope trend exists like that seen in the Slave craton (Kopylova et al., 200), and G10 garnets represent about $6 \%$ of all the pyropes (remember that the pyropes in this study were not selected by color, but rather represent the full population of garnets in the four kimberlites). 
A subset of the pyrope grains shown in Fig. 3 were analyzed for trace elements, including $\mathrm{Ni}$, as described in section 2. The corresponding Tni histograms (Fig. 4) show bimodal distributions using both the calibration of Ryan et al. (1996) and that of Canil (1999). This bimo-

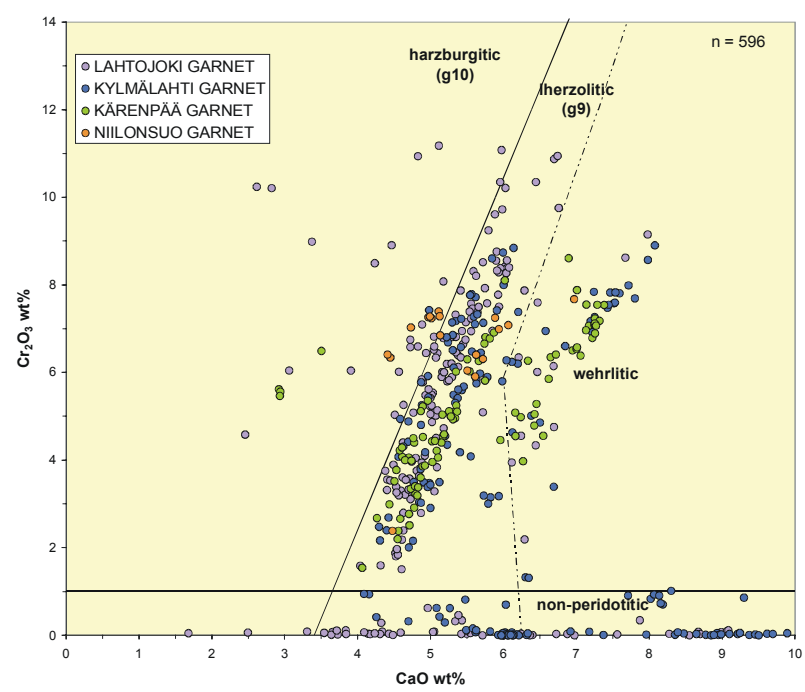

Figure 3: $\mathrm{CaO}$ vs $\mathrm{MgO}$ for garnets from 4 kimberlites from the Kaavi-Kuopio cluster, eastern Finland. Two kimberlites in particular are rich in 'wehrlitic' pyrope.

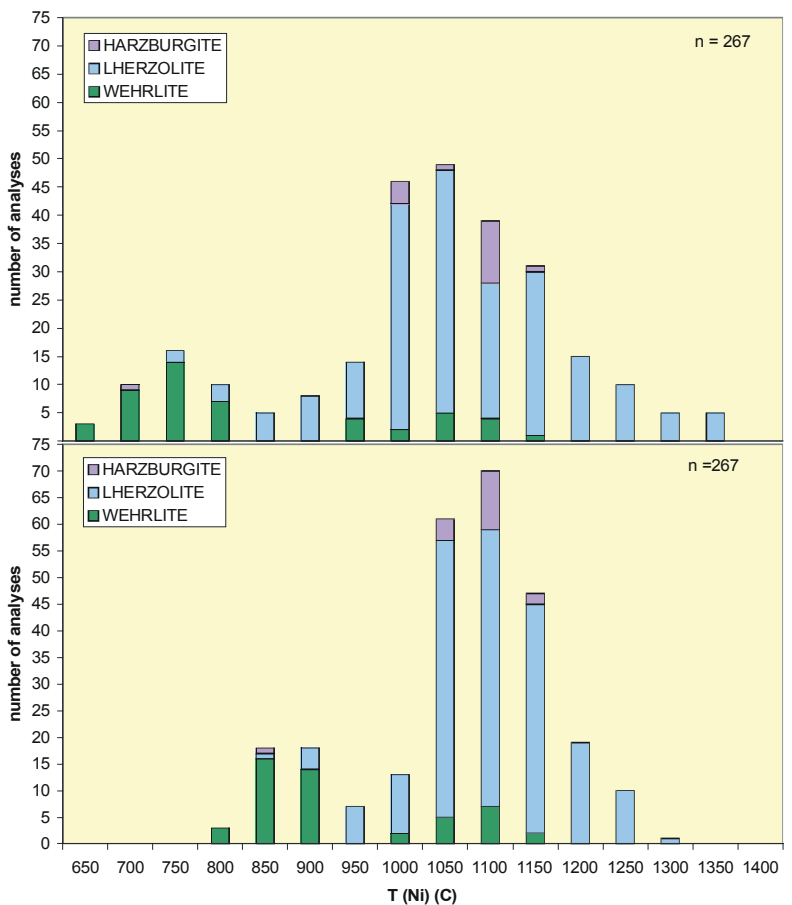

Figure 4: Distribution of TNi for trace element analyzed pyropes from this study comparing the calibrations of Ryan et al., 1996 (top) and Canil, 1999 (bottom). dal distribution includes a strong low temperature low Ti-Zr-Y 'wehrlitic' peak at 650 to $800{ }^{\circ} \mathrm{C}$ (TNi,Ryan used hereafter), and a stronger sampling peak at 1000 to $1150{ }^{\circ} \mathrm{C}$, which includes all but one of the G10 pyropes analyzed for $\mathrm{Ni}$ and a second population of more typical wehrlitic grains with elevated $\mathrm{Ti}, \mathrm{Zr}$, and $\mathrm{Y}$.

In addition to being the highest temperature at which the latter two pyrope types occur, $1150{ }^{\circ} \mathrm{C}$ also represents a break in the stratigraphic section of the mantle based on $\mathrm{Zr}$ contents, separating mantle that contains strongly depleted pyropes from more enriched mantle (Fig. 5). Also plotted in Fig. 5 are analyses of megacryst composition, Ti-rich pyropes (TiPs) that are plotted for illustrative purposes, as they may not have been in equilibrium with mantle olivine. We defend the reasoning of plotting at least the most Mg-rich TiPs on this diagram as they reach the same $\mathrm{Mg}$ contents as lherzolitic pyropes implying equilibration with olivines similar to those in the lherzolites. Significantly the great bulk of TiP analyses plot above the $1150{ }^{\circ} \mathrm{C} \mathrm{Zr}$ edge.

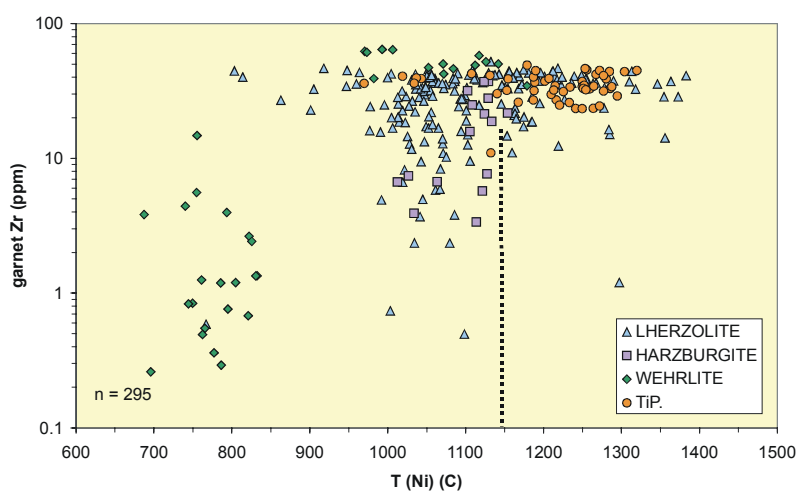

Figure 5: Pyrope $\mathrm{Zr}$ content vs. TNi for pyropes showing a $\mathrm{Zr}$ edge at about $1150^{\circ} \mathrm{C}$. This $\mathrm{Zr}$ edge does not mark the lower boundary of the lithospheric mantle, as all xenoliths from $>1150{ }^{\circ} \mathrm{C}$ are coarse granular SLCM peridotites.

The two breaks in mantle stratigraphy underlying Kaavi-Kuopio also show up well using Ti contents of the pyropes, as in Fig. 6, where the TNi temperatures have been extrapolated to the local geotherm (Kukkonen and Peltonen, 1999) to give pressures for each grain. The lower temperature boundary at about $850{ }^{\circ} \mathrm{C}$ corresponds to the break in $\mathrm{TiO}_{2}$ at about 110 $\mathrm{km}$ depth, above which only extremely low $\mathrm{TiO}_{2}$ content pyropes exist, most of these being 'wehrilitic' in composition, although one G10 and several G9 grains similarly depleted in $\mathrm{TiO}_{2}$ also occur. The second boundary roughly at $1150{ }^{\circ} \mathrm{C}$ or ca. $180 \mathrm{~km}$ is manifested as the limit below which only a very few $\mathrm{TiO}_{2}$-depleted pyropes occur. However, the existence 
of these few grains is significant because it may suggest that the lower mantle layer was at one time was also depleted but has been refertilized by melt metasomism

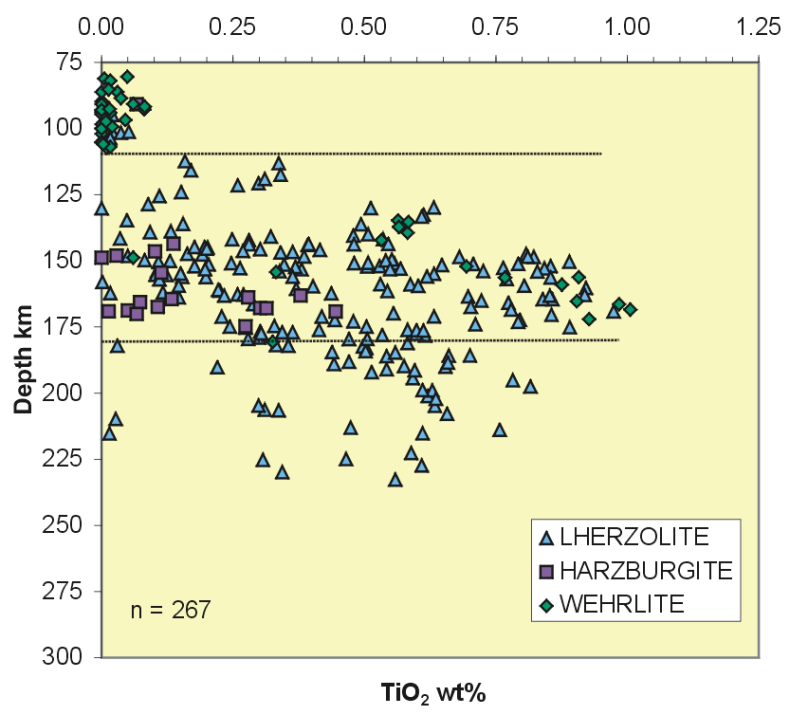

Figure 6: $\mathrm{TiO}_{2}$ vs. depth for the Kaavi-Kuopio pyropes showing the three distinct layers of the underlying mantle. causing the destruction of all harzburgitic material and crystallizing Ti-rich pyropes; the latter possibly as a network of dikes and pods.

These relationships are shown schematically in Figure 7 where the suture between the Archean and Proterozoic is drawn as a nearly vertical boundary. The continental lithospheric mantle is represented by 3 distinct layers: 1. An upper layer distinguished by extremely low TiZr-Y 'wehrlitic' pyropes. Only three xenoliths from this layer have been collected, all modally harzburgites, and all containing the same anomalous, trace element depleted but Ca-enriched 'wehrlitic' pyropes. 2. A middle lherzolite to harzburgite layer (with minor werhlite) representing the unit most sampled by the kimberlites. The graphite - diamond stability curve (Kennedy \& Kennedy, 1976) cuts across this layer and implies a diamond window in the Kaavi-Kuopio mantle between $140 \mathrm{~km}$ and $180 \mathrm{~km}$, the upper stability limit of diamond, and the lower limit of mantle with a remnant depleted harzburgitic (G10) signature; a roughly $40 \mathrm{~km}$ wide prospective zone. 3 . A lower melt metasomatized layer with a minor amount of remnant depleted material suggesting a previous history as a deeper extension of layer 2 .

\section{Svecofennian mobile belt Karelian craton}

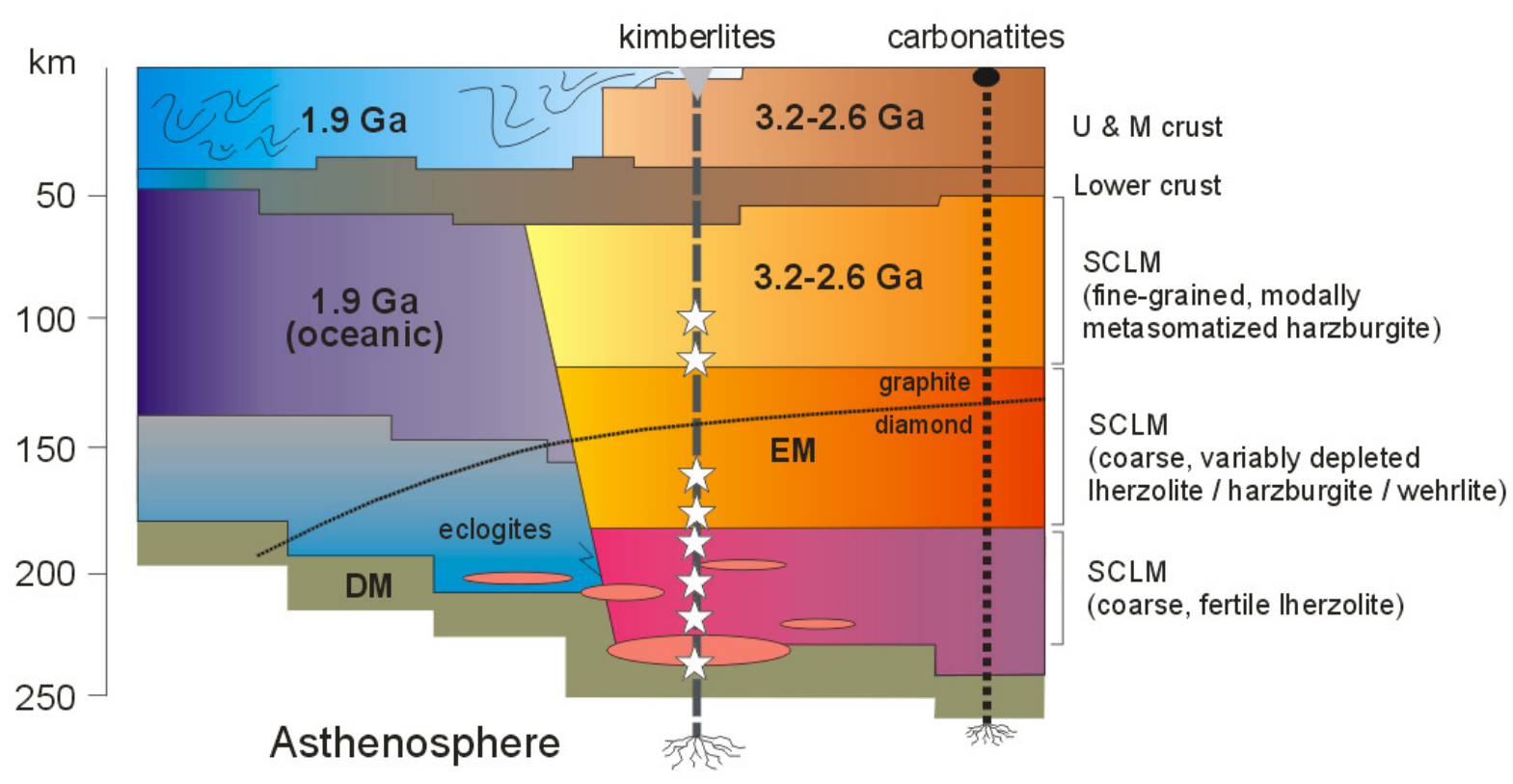

Figure 7: Schematic cross-section through the rifted and redocked edge of the Karelian craton showing the three distinct petrologic layers in the mantle inferred from pyrope compositions. 


\section{REFERENCES}

Brey, G.P., Köhler, T \& Nickel, K.G. 1990. Geothermobarometery in four-phase lherzolites I. Experimental results from 10 to $60 \mathrm{~kb}$. J. Petrol. 31, 1313-1378.

Calcagnile, G., 1982. The lithosphere-asthenosphere system in Fennoscandia. Tectonoph. 90, 19-35.

Canil, D. 1999. The Ni-in-garnet geothermometer: calibration at natural abundances. Contrib. Min. Petrol. 136, 240246.

Gaál, G. \& Gorbatschev, R., 1987. An outline of the Precambrian evolution of the Baltic Shield. Precambrian Res. 35, 15-52.

Griffin, W.L., Cousens, D.R., Ryan, C.G., Sie, S.H. \& Suter, G.F., 1989. Ni in chrome pyrope garnets: A new geothermometer. Contrib. Mineral. Petrol. 103, 199202.

Gurney, J.J., 1984. A correlation between garnets and diamonds. In: Glover J.E. and Harris P.G. (eds.), Kimberlite Occurrence and Origin: A basis for conceptual models in exploration. Geol. Dept. and Univ. Ext., Univ. of WA, Publ. 8, pp. 143-166.

Kennedy, C.S. \& Kennedy, G.C., 1976. The equilibrium boundary between graphite and diamond. J. Gephys. Res. 81, 2467-2470.

Kontinen, A., Paavola, J., \& Lukkarinen, H. 1992. K-Ar ages of hornblende and biotite from Late Archean rocks of eastern Finland; interpretation and discussion of tectonic implications. Geol. Surv. Finland Bull. 365, $31 \mathrm{pp}$.

Kopylova, M.G., Russell, J.K., Stanley, C. \& Cookenboo, H., 2000. Garnet from Cr- and Ca-saturated mantle: implications for diamond exploration. J. Geochem. Explor. 68, 183-199.

Kukkonen I.T. and Jõeleht A., 1996. Geothermal modelling of the lithosphere in the central Baltic Shield and its southern slope. Tectonophysics 255, 24-45.

Kukkonen, I.T. \& Peltonen, P., 1999. Xenolith controlled geotherm for the central Fennoscandian Shield: Implications for lithosphere-astenosphere relations. Tectonoph. 304 (4), 301-315.

Nimis, P. \& Taylor, W.R., 2000. Single clinopyroxene thermobarometry for garnet peridotites. Part I. Calibration and testing of a Cr-in-cpx barometer and an enstatite-in-Cpx thermometer. Contrib. Min. Petrol. 139, 541-554.

O’Brien, H.E. \& Tyni, M., 1999. Mineralogy and geochemistry of kimberlites and related rocks from Finland. In: Gurney, J.J., Gurney, J.L., Pascoe, M.D. and Richardson, S.H. (Eds.), Proceedings of the 7th International Kimberlite Conference, pp. 625-636.

Peltonen, P., Huhma, H., Tyni, M. \& Shimizu, N., 1999. Garnet peridotite xenoliths from kimberlites of Finland: Nature of the continental mantle at an Archaean craton - Proterozoic mobile belt transition. In: Gurney, J.J., Gurney, J.L., Pascoe, M.D. and Richardson, S.H. (Eds.), Proceedings of the 7th International Kimberlite Conference, pp. 664-675.

Peltonen, P. \& Mänttäri, I., 2001. An ion microprobe U-Th$\mathrm{Pb}$ study of zircon xenocrysts from the Lahtojoki kimberlite pipe, eastern Finland. Bull. Geol. Soc. Finland 73, pp. 47-58.

Pollack, H.N. \& Chapman, D.S., 1977. On the regional variations of heat flow, geotherms and lithosphere thickness. Tectonoph. 38, 279-279.

Robinson, B.W. \& Graham, J. 1992. Advances in Electron Microprobe Trace Element Analysis. J. ComputerAssisted Microsopy 4, 263-265.

Ryan, C.G., Griffin, W.L. \& Pearson, N.J., 1996. Garnet geotherms: Pressure-temperature data from Cr-pyrope garnet xenocrysts in volcanic rocks. J. Geophys. Res. 101, 5611-5625.

Sobolev, N.V., Lavrentìev, Yu.G., Pokhilenko, N.P. \& Usova, N.P., 1973. Chrome-rich garnets from the kimberlites of Yakutia and their paragenesis. Contrib. Mineral. Petrol. 40, 39-52.

Tyni, M., 1997. Diamond prospecting in Finland - a review. In: Papunen H. (edit.), Mineral Deposits: Research and Exploration, Where do They Meet? Proceedings of the $4^{\text {th }}$ SGA Meeting, pp.789-791.

Vaasjoki, M. \& Lindqvist, K., 2001. Electrodynamic fragmentation tests aimed at separation of mineral species for mineralogical and isotopic studies. Geol. Surv. Finland, Rep. Inv. M 41.1/2001/2, 18 pp.

Contact: ML Lehtonen, PO Box 96, FIN-02151 Espoo,

Finland, E-mail: marja.lehtonen@gsf.fi 